Hacettepe Üniversitesi Edebiyat Fakültesi Dergisi
Hacettepe University Journal of Faculty of Letters
Cilt/Volume: 35 Sayl/Number:2
Aralı/December 2018
doi: $10.32600 /$ huefd.430391

\title{
Delilik Oyunu: Bir Homo Ludens Olarak Hikmet Benol*
}

\author{
H. Furkan LiVAN ${ }^{* *}$
}

\author{
Game of Madness: Hikmet Benol as a Homo Ludens
}

\begin{abstract}
Öz
Bu çalışma, gerçek ile kurgu arasındaki ilişkiyi Oğuz Atay'ın "Tehlikeli Oyunlar" adlı metnine atıfta bulunarak eleştirel bir bakış açısı ile ele almaktadır. Makale, yaşam gerçekliğini bir metnin kurgusundan kesin olarak ayıramayacağımız fikrine dikkat çekmektedir. Dolayısıyla, metnin temelinde gerçeklik ve kurgu ayrımının eleştirisi vardır. Johan Huizinga'nın oyun oynayan insan anlamına gelen homo ludens kavramı, bu noktada kritik bir hususa işaret eder. Homo ludens, oyun oynayarak gerçekliği kendi başına yaratan insandır. Gerçekliğin yaratılması, onun (gerçekliğin) özsel olmayan mahiyetini ifade etmektedir. Bu nedenle gerçeklik, aslında kurgudan ayrılamaz olan şeklinde tanımlanabilir. Çalışmanın temel amaçlarından biri, Oğuz Atay'ın “Tehlikeli Oyunlar”ının ana karakteri olan Hikmet Benol aracılığıyla gerçeklik-oyun, gerçeklik-anlatı, oyun-ciddiyet, logos-kaos gibi çeşitli ikili karşıtlıkların eleştirisini vermektir. Bilindiği gibi, bu tür ikili karşıtlıklar -Martin Heidegger'in ve Jacques Derrida'nın ifadesiylemevcudiyet metafiziğinin unsurlarıdır. Mevcudiyet metafiziği kavramı, Platon'dan bu yana süregelen Batı düşünce geleneğinin bir tür yorumudur. $\mathrm{Bu}$ yorum, beraberinde metafizik Batı düşünce geleneğinin eleştirisi fikrini getirmektedir. Çalışmada, bahsi geçen eleştirinin akıl, delilik ve oyun bağlamına odaklanılmıştır. Oğuz Atay'ın romanlarında ve öykülerinde sıklıkla anormal, topluma yabancılaşmış ve yalnızlaşmıs karakterlere rastlanmaktadır. Oğuz Atay'dan bahsedilirken ilk akla gelen metin "Tutunamayanlar" olsa da, en tutunamayan, en deli, en aykırı karakteri "Tehlikeli Ouynlar"daki Hikmet Benol'dur. Bu bağlamda, Atay, belirli normlara uymama, logos düzenine karşıt olma ve günlük yaşamdaki normallerden ayrı olma yoluyla oyunu ve deliliği kullanmaktadır. Burada, Hikmet Benol'un yaşadığı temel sorun olarak varoluş/varolma ve bireyselleş(eme)me sorunlarını ortaya koymak suretiyle, ironinin ve alaycı düşüncenin, varlığın, ölümün/intiharın merkezi rolünü tartışmak amaçlanmıştır. Böylece çalışmada, oyunun kurmacalığının önemi ve delilik mefhumunun a/normalliği, eleştirel bir hayat felsefesi gözetilerek tartışılmaktadır.
\end{abstract}

Anahtar Sözcükler: Homo Ludens, delilik, oyun, Tutunamayanlar, Oğuz Atay

\begin{abstract}
This study takes a critical view of the relationship between truth and narrative with reference to Oğuz Atay's prose work entitled "Tehlikeli Oyunlar" (Dangerous Games). The paper draws attention on the idea that we cannot separate the reality of life precisely from the fictionality of a text. Thus, the critique of the separation of reality and fiction lies at the basis of the text. Johan Huizinga's concept of homo ludens which means the human being who plays games implies a critical marker at this point. Homo ludens is a human being who creates reality by playing games. Creation of reality refers to its (reality's) non-essential character. For this reason, reality can be described as inseparable from fiction. One of the major aims of this work is to critically interpret dual oppositions like reality-game, reality-narrative, game-seriousness, logos-chaos through Hikmet Benol who is the main character of Oğuz Atay’s "Tehlikeli Oyunlar". It is known, such binary oppositions -in Martin Heidegger's and Jacques Derrida's terms- are elements of metaphysics of presence. The notion of metaphysics of presence is a kind of interpretation of the tradition of Western thought that

\footnotetext{
* Bu çalışma, Hacettepe Üniversitesi'nde Consortium for Research in Political Theory (CRIPT) tarafından düzenlenen Political Theory and Cultural Studies: Other Voices and New Perspectives (2017) adlı kongrede “Deliliğin Yarasi: Bir Homo Ludens Olarak Hikmet Benol” başlı̆̆ıla sunulan bildirinin zenginleştirilmiş makale versiyonudur. Bildiride ve bu yazının ortaya çıkmasında emeği geçen hocalarım Doç. Dr. Ruhtan Yalçıner'e ve Dr. Öğr. Üyesi Kadir Dede’ye müteşekkirim.
}

** Araş.Gör., Hacettepe Üniversitesi, İktisadi ve İdari Bilimler Fakültesi, Siyaset Bilimi ve Kamu Yönetimi, furkanlivan@hacettepe.edu.tr
\end{abstract}


dates back to Plato. This interpretation brings the idea of critique of the metaphysical tradition of Western thought. In this work, the focus is on the logos (mind), madness and game context of this criticism. Oğuz Atay's novels and stories often contain abnormal and isolated characters who are alienated from the society. Although, "Tutunamayanlar" (The Disconnected) is the work that first comes to mind when Oğuz Atay is mentioned, the most disconnected, the maddest, the most anomalous character is Hikmet Benol of "Tehlikeli Oyunlar". In this context, Atay uses game and madness through failure to comply with certain norms, contradictions to the logos order, or the sense of being disconnected from the signs of the 'normal' in daily life. By introducing the problem of existence and (dis)individuation as the basic problems experienced by Hikmet Benol, this paper aims to discuss the central role of irony and mockery, existence, death/suicide. In this paper, thus, the importance of the fictionality of the game and the ab/normality of madness is discussed by taking a critical philosophy of life into consideration.

Keywords: Homo Ludens, madness, game, Tutunamayanlar, Oğuz Atay

\section{Giriş}

Bu çalışma, Oğuz Atay'ın “Tehlikeli Oyunlar” adlı eserini ve özelde ise bu eserin baş karakteri olan Hikmet Benol'u yorumlama önerisidir. Çalışmanın çıkış noktası, "Tehlikeli Oyunlar" adlı eserin nasıl okunabileceği ve hangi kavramlarla bağlantılı olarak yorumlanabileceği hususudur; ve bu yönde, delilik ve oyun kavramları temel öneme sahip iki kavram olarak karşımıza çıkmaktadır. Konusu böylece özetlenebilecek olan bu çalışmanın yöntemi ise bir tür hermeneutik metin analizi olarak ifade edilebilir. Yani, ele alınan metin ("Tehlikeli Oyunlar"), belli bir bağlam içerisinde (delilik ve oyun kavramları), metnin yazarı (Oğuz Atay) ve yazıldığı dönemin koşulları göz ardı edilmeksizin, bu çalışmayı üreten yazarın kendi tarihselliğini de işin içine katarak bir tür alternatif okuma/yorumlama sürecine tabi tutulmaktadır.

Bilindiği üzere, Oğuz Atay’ın kaleminden çıkan, "Tutunamayanlar" ve "Tehlikeli Oyunlar" romanları, dünya çapında değerlendirildiğinde, dönemin romancılığında egemen olan eleştirel bir anlayışın örneği olarak ifade edilebilecek eserlerdir. 19. yüzyıl romancılığının pozitivist ve materyalist dünya görüşüne göre şekillenmiş muhtevası, 1920'lerde ortaya çıkan James Joyce, Franz Kafka, Robert Musil gibi yazarların eserleri sayesinde farklı bir çehreye bürünmüştür. (Moran, 2001, s. 263). Oğuz Atay'ın yazarlığında da hem içerik açısından hem de teknik ve üslûp açısından bu isimlerin etkileri oldukça fazladır. "Onlar için karşıtlıkların birlikte kullanımı modern yaşamın ya da insanın içsel dünyasındaki kargaşanın/çözümsüzlüğün/aporianın kurgu düzlemindeki izdüşümüdür. Belirli bir türde takılıp kalmamak, geleneksel üç ana türü: lirik-epik-dramatik ya da şiir-anlatı-tiyatroyu bir arada kullanmak, giderek melez türler oluşturmak da modernist poetikanın ana eğilimlerinden biridir." (Ecevit, 2014, s. 357). Oğuz Atay'da gördüğümüz modern roman anlayışından postmodern roman anlayışına doğru bükülen bu yaklaşım, gerçeklik ve yaşama dair birtakım kuşkucu ve eleştirel argümanları içinde barındırmaktadır. $\mathrm{Bu}$ argümanların en önemlilerinden birisi ironi ve alayla şekillenen, gerçekliğin ve hakikat iddiasının her adımda -Derrida'cı bir temelden konuşmak gerekirse- dekonstrüksiyona ${ }^{1}$ maruz bırakıldığı ve bu iddiaların bir tür différance ${ }^{2}$ karakteriyle birlikte kendini temellendirdiği anlatılar olarak üretilmesidir.

Atay’ın roman anlayışının da -“Tehlikeli Oyunlar”da da gördüğümüz gibi- içinde bulunduğu "postmodernistlere göre romanın işlevi 19. yüzyıl gerçekçilerinin sandığı gibi insan, dünya ve toplum hakkında göstergesel bir anlamı olan görüşler bildirmek, gerçekliği yansıtmak değildir.” (Moran, 2001, s. 264). Dolayısıyla, postmodern roman anlayışında temel farkın hakikat ve anlatı-gerçeklik mütekabiliyetine dayanma hususundaki eleştirel tutum olduğu söylenebilir. Bu anlamda Oğuz Atay, Türk romanında gelenekselleşmiş gerçekçi ve toplumcu, politik meseleleri ön plâna koyan ve çözüm arayan roman anlayışından kopuşun örneği olarak görülebilir. Bunu söylerken, Atay'ın romanlarındaki aydın eleştirisi, Batıcllı ve özenti aydın karakterinin hicvedilmesi gibi temel meselelerin altı da çizilmeli, içerisinde ironiye ve alaya dayanan keskin bir eleştirel tutumu barındırdığı es geçilmemelidir.

Ancak, aydın ve Batıcılık eleştirilerinin makul miktarda bulunmasının yanı sıra, açıktır ki Oğuz Atay'ın temel sorunsalı tutunamayanlardır. "Bütün yapıtlarında eleştiriyi eksene almış bir yazar Oğuz Atay.

\footnotetext{
${ }^{1}$ Ayrıntı için bkz.: Ramond, 2011 ve Lucy, 2012.

${ }^{2}$ Ayrıntı için bkz: Derrida, 1982.
} 
Bir bakıma içerik açısından hep tutunamayanları yazmıştır. Dolayısıyla bir anlamda toplum eleştirisi getiriyor ama alıştığımız anlamda bir toplum eleştirisi değil. Belli bir düzenin, bu düzenin yarattığ çelişkilerin nedenli sonuçlu eleştirisi değil; yabancılaşmış kişilerin tutunamayışını sergiliyor yazar." (Akatlı, 2012, s. 44). Peki tutunamayan derken kastedilen nedir diye sorulacak olursa, doğrudan şu şekilde yanıt verilebilir: "Disconnectus erectus'un karşıladığı, Türkçesine 'tutunamayan' denen, 'beceriksiz ve korkak bir hayvan'dır." (Aygün, 2012, s. 146). Beceriksizliği ve korkaklığı, gündelik yaşamın ortasında bir tür varoluş problemi ve bireysel anlamda bir kimliklenememe sorunu olarak kendini göstermektedir.

O halde, özetle ifade edecek olursak, Oğuz Atay’ın eleştirel konumunu tanımlarken modern roman ile postmodern roman unsurlarının eleştirelliğini keskin bir biçimde yansıttığı, kurgu açısından postmodern özellikleri (metinlerarasılık, üstkurmaca vs. gibi) barındırdığını ve modern romandan kopuşun örneklerini verdiğini söylemek mümkündür. Bu noktada, bu çalışmanın özgün yanına değinilecek olursa; Atay'ın "Tehlikeli Oyunlar"1nı ve özelde Hikmet Benol karakterini, iki kavram ile birlikte düşünme önerisi olarak ifade edilebilir. Bu kavramlar oyun ve delilik kavramlarıdır. Dolayısıyla amaç, Atay'ın tutunamayan karakterlerini -ve en tutunamayan karakteri olan Hikmet Benol'u- okumanın eleştirel bir biçimi olarak oyun ve delilikle, bir başka ifadeyle delilik oyunu ile anlamaya gayret etmektir. Şu noktada oyun ve homo ludens kavramlarının ne anlama geldiğine bakmadan önce, delilik hususunun tutunamayan kavramıyla bağlantısına ve logos karşıtlığı irtibatına odaklanmak yerinde olacaktır.

\section{Delilik ve Disconnectus Erectıs}

Delilik kavramı, tarihsel bir anlamlar deryasının en uç, en anlaşılamaz, en konuşulamaz kavramlarından bir tanesidir. Deliliğin bu çalışma bağlamında ele alınması önemlidir, çünkü çalışmadaki kavramları, ele alınan metnin neden önemli olduğunu anlamamızı sağlayacak olan en kilit, en temel kavram deliliktir. Delilik unsurunun roman karakterlerine kattığı anlamın ortaya konması, delilik özelliği ile nelerden kaçınılıp nelerin vurgulandığının gösterilmesi önemlidir. Çünkü delilik normal olmayan yaşamların üst başlığıdır. Bu anlamda, bu çalışmada Delilik teması etrafında bir tür logos-madness (söz/akıldelilik) karşıtlığının tartışması yapılabilir olmaktadır. O halde, epistemolojik soruyu sorarak başlamak yerinde olacaktır: Delilik nedir?

Delilik mefhumu üzerinde en kapsamlı çalışmalardan biri -belki de en kapsamlısı- olan, Michel Foucault'nun "Deliliğin Tarihi”" adlı eseri, bu konuyu aydınlatmada öncü bir rol oynamaktadır. Çağdaş düşüncede delilik kavramı üzerinde ayrıntılı şekilde durulmuş, bununla birlikte belli bakış açılarıyla (örneğin, psikanalizin bakışıyla) ele alınmaktan pek de kurtulamamış bir kavramdır. Felsefe tarihinde, aklın konumuyla birlikte deliliğin tartışılması da farklı veçhelerde gerçekleştirilmekle beraber, tarihsel bir bakışla farklı yaklaşımlarda karşımıza çıkan birbirine zıt anlamlarına değinmek yerinde olacaktır. Felman'ın belirttiği gibi (1975), günümüzde delilik (madness) önemli bir konu olarak ele alınmaktadır, hatta zaman zaman -Nietzsche'de olduğu gibi- felsefecilerin kendisiyle de bütünleşmiş bir durum söz konusu olabilmektedir. (s. 208)

"Deliliğin Tarihi” adlı eserinde Foucault, “ 'deli’nin hem ortaçağdan itibaren Batı toplumundaki tanımını irdeler hem de Batı toplumlarının tanımladıkları deliliği nasıl dışladıklarını ya da kabullendiklerini gün yüzüne çıkarır." (Vahapoğlu, 2014, s. 3). Buna göre farklı dönemlerde deliliğin nasıl farklı biçimde ele alındığını açıklayan kavramı, epistemedir. Foucault'ya göre delilik, Ortaçă̆-Rönesans dönemi (bu dönemde dinsel bir anlamla birlikte bazen kutsal ve ayrıcalıklı bile sayılabilmektedir), Klasik Çağ (Büyük Kapatılma dönemi) ve Modern dönem (Akıl hastalığı ile tanımlanan dönem) olmak üzere dönemlere ayrılarak ele alınabilmektedir. Bunun önemi ise, Foucault'nun özneyi belirleyen iktidar anlayışından kaynaklanmaktadır. Ona göre söylem (discourse) ile iktidar sahibi odakların belirlediği gerçeklik (yani episteme) o dönemin yaşamına yön veren sistemler bütünü olmaktadır. Dolayısıyla, delilik de her episteme döneminde farklı iktidar-özne ilişkileriyle, farklı araçlar sayesinde belirlenir olmaktadır. Bununla birlikte, ortak özellikler de mevcuttur. Deliliği bu kadar önemli kılan belki de en önemli özelliği, farklılık taşıyor olması; yani bir anlamda normların dışında konumlanmasıdır. Farklılık ve norm dışı olma durumu ise, genellikle bir tehdit 
olarak algılanması nedeniyle korkulan, uzaklaştırılan, bazen de kapatılan bir düşman olarak görülmüştür. Her zaman bir tür dışlamanın muhatabı olan delilik, Ŏguz Atay'ın tutunamayan kavramını, yani disconnectus erectusu açıklamak için de önemlidir. Zira, tutunamayan karakterler de varoluşa dair girdikleri hesaplaşma sayesinde/nedeniyle delilik treninin bir yolcusu olarak görülebilir.

Aydınlanma'nın, başat gerçeklik kaynağı olarak ele aldığ -Platon'dan bu yana aslında bir şekilde sürekli var olan- akla duyulan güvene dayalı rasyonalist anlayış, delilik kavramının anlaşılması için de bir firsat olarak okunabilir. Bu noktada Aydınlanma'nın en önemli isimlerinden biri olan Descartes'ın Cogito ergo sum! (Düşünüyorum, öyleyse varım!) yaklaşımının ve Kartezyen ikili karşıtlığın önemini vurgulamak gerekmektedir. Foucault ve Derrida arasında bir tartışma konusu da olan Descartes ve akıl-delilik karşıtllğ Batı düşüncesinin en mühim karşıtlıklarından biridir. Logosun karşıtı olan delilik (madness) Descartes için şüphenin de dişında kalan bir muhtevaya sahiptir. Ona göre delilik hem rüyadan hem de illüzyondan (yanılsamadan) farklıdır. Descartes, şüpheyi şüphe edilemeyecek olana, yani kendinin/benin varlığına dek götürürken, delilik unsurunu şüphenin bir aracı olarak bile hizmet etmeye izinli olmayan şey olarak görmektedir. Dolayısıyla, delilik, şüphe eden özne tarafından da dişlanmaktadır. (Felman, 1975, s. 210). Deliliğin bu dışlanmaya maruz kalması, tüm Batı düşünce tarihi için geçerli olmakta, felsefenin logosla irtibatlandığı, logos dışının felsefî olmayanla eşdeğer görüldüğü Antik dönemin bakışı Aydınlanma'ya dek uzanmaktadir.

Foucault'nun "Deliliğin Tarihi" (2015) adlı eserinde genişçe yer verdiği Büyük Kapatılma dönemi, en kapsayıcı anlamıyla deliliğin tecrit edildiği, büyük hastanelere ve hapishanelere binlerce kişinin kapatıldığ bir dönemi ifade etmektedir. (s. 85-135). Bu dönemde yalnızca Paris'te altı bin civarında insan (deliler, aptallar, alkolikler, meczuplar, yoksullar vs.) toplumun dişında tutulmuștur. ${ }^{3}$ Büyük kapatılma dönemi bir yandan toplum huzuru adına ortaya çıkarken, diğer yandan tamamiyle kontrol edilebilir bir toplum yaratmayı amaçlamıştır. Bu durumun, herkesin ortaklaşa normlarda anlaştığı bir gündelik hayat tahayyülü olduğunu söylemek mümkündür. Çünkü bu dönemde, çoğunluktan farklı olan herkes kapatmanın konusu olmuştur.

Dışlama ve kapatma, delilik karşısında akıllı dünyanın aldığı en önemli önlemlerdir. "Delilik klasik dönemde iki şekilde var olur; hastanelerdeki deliler ve kapatılanlar. İlkinde hukuki özne olan deli hastalıkla adlandırılmış hastanelere yollanmıştır. İkincisinde ise; toplumsal özne olan deli, kapatmayla çevrelenerek, toplum dışına itilmiştir." (Vahapoğlu, 2014, s. 29). Ancak, delilik meselesi tarihin her döneminde böyle bir dışlamaya ya da kapatmaya maruz kalmamıştır. Foucault'nun da belirttiği üzere, modernitenin akıl hastalı̆̆ ve psikiyatri meselesi olarak başka türden bir anormallik yüklediği delilik, Ortaçağ'da ve Rönesans'ta kutsanmaktadır. Delilik Ortaçağ' da bir dönem gündelik yaşamın bir parçası olarak görülmüştür. Onlara yapılan iyilik dinsel nedenlerle kutsal sayılmıştır. Kimi zaman da delilerin Tanrı'ya yakın olduğu düşünülmüştür. Deliliğin Rönesans döneminde en üst iyilik olarak sanat ve edebiyata dahil edildiği ve çok değer verildiği bir süreç yaşanmıştır. Foucault'ya göre bu dönemde insanları rahatlatan, korkularından arındıran, ferahlatan şeyler delilik sayesinde olmaktadır.

Bu noktada delilik üzerine önemli eseri “Deliliğe Övgü”yü yazmış olan Desiderius Erasmus'tan da bahsetmek yerinde olacaktır. Bu eserde önemli olan husus, hem Erasmus'un kullandığ1 ironi, hem de deliliğe verilen büyük değer ve onun özgürlükle ilgisidir. Erasmus'un delilik adına konuştuğu bu metin, 1511'de yazılmış; o döneme dek delilik mefhumunu daha ziyade Bosch'un Brueghel'in tablolarından, "Deliler Gemisi"nden müteşekkil bir anlayışla ele alınmıştır. Erasmus'la birlikte "delilik artık dünyanın dört bir yanında insanı eline geçirmek için pusuya yatmaktan çıkmıştır; insanın içine sinsice süzülmektedir veya daha doğrusu insanın kendi kendisiyle sürdürdüğü hassas bir ilişkidir. ... Delilik ancak her insanın kendinde olur, çünkü deliliği kendine bağl1lığı içinde ve beslediği yanılsamalar aracılığıyla oluşturan insandır. ... Delilik hakikat ve dünyadan çok, insanın algılayabildiği kendi gerçeğiyle ilgilidir." (Foucault, 2015, s. 55-

${ }^{3}$ Ayrıntılı bilgi için bkz: Scull, 2016. 
56). Erasmus'un “Deliliğe Övgü”sü bu anlamda akılla deliliği birlikte işleyen; bilgeliği, tanrısallığı ve deliliği özgürlük ve insanî koşullar bağlamında değerlendiren bir metin olarak düşünülebilir.

Erasmus'un yerdiği delilik, insana özgü deliliktir. Övgüler düzülen delilik ise, kutlu delilik, yani tanrısal olan, bu anlamda kutsal görülen deliliktir. Ancak, bilgelik ve delilik arasındaki sınır oldukça belirsizdir. "Bir kimsenin ruhu, bedeninin organlarını düzenli biçimde etkiledikçe, o kimse sağduyulu olarak kabul edilir. Ama ruh bağlarını koparıp özgürlüğe kavuşmaya, zincirlerinden kurtulmaya çalışırsa ona deli derler.” (Erasmus, 2008, s. 198). Delilik, Erasmus'a göre, insanı özgün yapan şeydir. Aynı zamanda da söyleme özgürlügüdür. "Ben insanlar arasında en deli olanıyım. Deli gibi konuşuyorum ama aslında daha fazla deliyim. Çünkü gerçekleri insanları gücendirmeden söylemek, deliliğe özgü bir ayrıcalıktır." (Erasmus, 2008, s. 190). Ayrıca, yaşamda zevk alınan her ne varsa, o delilikten dolayı gerçekleşebilmektedir.

Bu noktada Erasmus için açtığımız parantezi kapatmakta fayda var. Zira, Erasmus'un deliliği övmesi, esasında akılla bir tutulanların yerilmesini de getirmektedir. Yani delilik, esasında akıl ile birlikte var olabilmektedir. Foucault'ya göre: "Delilik ile akıl sürekli olarak tersine dönebilen bir ilişki haline girmektedirler, bu da her deliliği onu yargılayan ve ona egemen olan kendi aklına sahip; her aklı da onda gülünç gerçeğini bulduğu kendi deliliğine sahip hale getirmektedir. Her biri diğerinin ölçüsüdür ve bu karşılıklı atıf içinde bunların ikisi de birbirlerini reddetmekte, ama her biri diğerinin üzerine yaslanmaktadır." (Aktaran, Vahapoğlu, 2014, s. 9). Bunu da belirttikten sonra delilik meselesinin bir edebiyat metni ile ilişkisine kadar bizi götürecek olan Derrida'nın argümanlarına göz atmak yerinde olacaktır.

Derrida, Foucault'nun "Deliliğin Tarihi” adlı metnine birçok noktada katılmakla birlikte, bazı hususlarda onun eleştirisini de vermektedir. Eleştiriye konu olan nokta, esasında böyle bir çalışmanın kendi iç çelişkisi gibi görünmektedir. Kendi iç çelişkisi, delilik üzerine söz söylemenin imkânı tartışmasında karşımıza çıkar. Derrida'ya göre, deliliğin kendisine göre değerlendirdiğimizde, dil her zaman başka bir yerdendir. (Felman, 1974, s. 216). Foucault'nun yaşadığı zorluk da bundan kaynaklanır. Ona göre Deliliğin tarihini yazmak, aslında aklın tarihini yazmak olmak zorundadır, çünkü sözün (logosun) içerisinden konuşulur.

Derrida'nın eleştirisinden şunu net olarak çıkarmak mümkündür; delilik, logos (hem akıl hem söz anlamlarıyla) tarafından dışlanmış olandır, dolayısıyla logos içinde delilik tartışması yapmak her halükârda logosun içinde kalmayı gerektirmektedir. Eğer deliliği var etmeye çalışırsak, yalnızca ve yalnızca susmamız gerekir. O halde şunu söylemek de mümkün olur; delilik, felsefeden kaçmaktadır. Delilik felsefeden kaçarak başka bir yere sığınır. İşte Derrida bu sığınağın edebiyat olabileceğini ifade etmektedir. Deliliğin sessizliği, logos içinde söylenmez, ancak onun ruhu tarafından sunulabilir ve bu ancak ve ancak metaforik bir biçimde gerçekleşebilmektedir. (Felman, 1974, s. 219). Felman'a göre, esasında bu noktada Foucault ve Derrida anlaşmaktadır. Edebiyat, delilik ve felsefe arasında arabuluculuk yapmaktadır. ${ }^{4}$ (Felman, 1974, s. 223). Edebiyatın arabuluculuğu, ontolojik bir meseleyi söylem düzleminde tartışılabilir kılmayı sağlamasıdır. "Foucault, tarihsel süreçte, farklı farklı tanımlamalarla dışlanan 'deli'ye 'farklı' olma hakkını geri vermek ister.” (Vahapoğlu, 2014, s. 56). Erasmus, deliliği yaşamın mutlu kılınabilmesinin yolu olarak görür. Derrida ise tartışmayı logosentrik Batı metafiziğinin eleştirisiyle dekonstrüktif bakışa yerleştirerek, deliliğin imkânını dil üzerinden edebiyata bağlar.

Tüm bu tartışmalarla geldiğimiz nokta, Oğuz Atay’ın öykülerinde ve romanlarında karşımıza çıkan karakterlerin tutunamama halinin gösterdiği üzere, bu konunun temel mesele olarak alınmasının, aklın egemenliğine (bir anlamda logosentrik bakışa) eleştiri olarak ele alınabileceğinin iddia edilmesidir. Çünkü Artaud, Hölderlin, Nietzsche ve Van Gogh gibi isimlerin maruz kaldığ 1 baskı Hikmet Benol’un, Selim

\footnotetext{
${ }^{4}$ Delilik mefhumunun gerçek ve kurmaca bağlamında edebiyatta nasıl işlevsel/araçsal bir mahiyete kavuşabileceğine; bu anlamda metaforik kalmanın yanı sıra, gerçek hayatın siyasal baskısına (yani bir anlamda baskıcı logos düzenine karşı çıkabilmenin imkânı olarak ele alınabileceğine) dair ufuk açıcı bir çalışma için bkz.: Dede, 2016.
} 
Işık'ın ve Beyaz Mantolu Adam'ın maruz kaldığı baskıdan farklı değildir. Belki filozofların gerçek delilikleriyle birlikte dehalarını tarihüstü bir noktaya taşımalarından farklı olarak, Oğuz Atay'ın karakterlerinin gündelik yaşam içinde kalan sıradanlığını vurgulamak gerekmektedir. Bu noktada, delilik kavramını bir anlamda sahiplenen ve sindiren, böylece logosa dahil oyunlardan uzaklaşarak kendi özgür oyunlarını -yani delilik oyunlarını- oynamaya yönelebilen oyuncuların ve oyun alanlarının niteliğine bakmak yerinde olacaktır. Delilik, bizi varoluşsal bir özgürlük alanine götürürken, araç olması gereken oyun meselesi de bu noktada ön plana çıkar.

\section{Oyun ve Homo Ludens}

Oyun kavramı, tarihsel kullanımları göz önünde tutulduğunda, genel itibariyle felsefî soruşturmalara konu olmuş; kültürle ve varoluş sorunu ile ilgili, Varlık'ın konumunu eleştirel bir bakışla ele alma noktasında kişinin yaşam karşısında -ya da içerisinde, veya yaşamla birlikte- günlük hayatta nasıl davrandığı ve nasıl tutum alabileceği meselelerine dokunan bir husus olarak bir çok düşünür tarafından ele alınmıştır. Bu çalışma için oyun mefhumunu bu kadar önemli kılan nokta, Tehlikeli olan oyunların ("Tehlikeli Oyunlar"ın) nasıl bir muhtevaya sahip olduğunu anlama çabasıdır. Oyun nedir, oyun nasıl ele alınabilir, oyun nasıl olur da ontolojik bir endişenin ana öğesi olarak değerlendirilebilir? 20. yüzyıl düşünürleri arasında bu soruya cevap vermeye çalışan Nietzsche, Heidegger, Gadamer, Derrida gibi birçok önemli filozof vardır. ${ }^{5}$ Ancak, bu çalışma için en çok önem arz eden isimler, öncelikle homo ludens kavramıla oyunu ele alan -ayrıca aynı isimle bir de eseri bulunan- Johan Huizinga ${ }^{6}$ ve Huizinga'nın oyun ve oyun oynayan insan (homo ludens) tanımlarını yaşamın bir parçası olarak varoluşsal çizgilere çekmeyi mümkün kılan Eugen Fink ${ }^{7}$ tir. Aynı zamanda, Derrida'nın différance ve dekonstrüksiyon yaklaşmı bağlamında oyunu bir yaşam unsuru olarak yorumlama çabası da öne çıkan bir argümandır.

Huizinga, oyun mefhumunu kültürle irtibatı nezdinde değerlendirmektedir. Ona göre oyun, kültürden daha kapsamlıdır ve kültüre önceldir. Huizinga'ya göre oyun, "belli bir zaman ve mekân sınırları içinde gerçekleştirilen, bizatihi bir amaca sahip olan, bir gerilim ve sevinç duygusu ile, 'alışılmış hayat'tan 'başka türlü olmak' bilincinin eşlik ettiği, iradi bir eylem ve faaliyettir.” (Huizinga, 2015, s. 50). Dolayısıyla oyun, Huizinga'nın argümanlarında bir gerçek gündelik yaşam içinde açılan parantez gibi görülebilir. Bunun yanı sıra, genel olarak oyunun bir ciddiyet karşıtı konumda ele alındığını söylemek de mümkündür. Ancak, Huizinga'da oyunun ciddiyet mefhumunun zıttı olarak görülmediği, aksine, hem ciddi olanın hem de ciddi olmayanın onun tarafından içerilebildiği ifade edilebilir. (Huizinga, 2015, s. 68-69). Yani, Huizinga'da oyun-ciddiyet ikili karşıtlığı var gibi görünse de, esasında ona göre oyun hem ciddi olanı, hem de ciddi olmayanı içerebilme potansiyelini haizdir., eğlence, ironi, alay gibi unsurları da oyunun bir parçası haline getirmektedir.

Metin And'ın özetlediği şekilde ifade edilecek olursa, Huizinga'nın argümanlarında oyun mefhumunun başlıca şu üç temel özelliğinden bahsetmek mümkündür:

i) “Oyun her şeyden önce isteğe bağl1, gönüllü bir eylemdir. ... Böylece, oyunun bir önemli niteliği ortaya çıkıyor, bu da onun özgürlüğüdür." (And, 2012, s. 28).

Dolayısıyla, oyunların farkına vararak, oyunları delilik oyunlarına dönüştürerek, özgürleşmenin bir aracı k1lmak mümkün hâle gelmektedir.

\footnotetext{
${ }^{5}$ Bahsi geçen isimlerin oyun ve ontoloji bağlamında argümanlarını değerlendiren ayrıntılı bir kaynak olarak bkz. Dursun, 2014. Özetle kişiler ifade edilecek olursa; bu metinde karşımıza çıkan isimler, öncelikle Antik Yunan'dan Herakleitos ve Platon olarak karşımıza çıkmakta; onlara göre oyun, felsefî-toplumsal bir anlamı haiz olarak ele alınmaktadır. Ancak, bu çalışmadaki varoluşsal noktayı açığa çıkaran en önemli isimler, modern dünyayı eleştirmenin belki de en kapsamlı ve ontolojik örneklerini veren Nietzsche ve Heidegger'de karşımıza çıkmakta; oyun, aion, physis, logos, kosmos gibi Antik Yunan temelli kavramların varlıkla irtibatı bağlamında ve gücü isteme oyunu olarak ele alınmaktadır.

Heidegger'de Dasein'dan bağımsız olmayan -ancak yine de üstü kapalı olarak ele alınan bir tür oyundan bahsetmek mümkündür. Buna karşın, Derrida'ya geldiğimizde oyun, différance hareketine uygun bir biçimde, postmodern argümanlarının ve dekonstrüksiyon mentalitesinin bir parçası olarak karşımıza çıkmaktadır.

${ }^{6}$ Huizinga'nınn bahsi geçen eseri için bkz.: Huizinga, 2015.

${ }^{7}$ Fink'in oyun kavramını ele aldığı yapıtı için bkz.: Fink, 2015.
} 
ii) "İkinci bir niteliği, gene onun özgürlüğü ile ilgilidir, bu da oyunun gerçek yaşam, günlük yaşamdan değişik oluşudur. Oyun, gerçek yaşamdan geçici olarak çıkarak kendi düzeninin, dünyasının içine girer." (And, 2012, s. 28).

Oyun oynanırken oyunun kuralları başlar ve oyuncu bunun farkındadır. Dolayısıyla oyun, gündelik yaşama bir ara veriş, gündelik yaşamın kesintiye uğratılması gibidir.

iii) "Üçüncü niteliği, oyununun, günlük yaşamdan yer ve süre bakımından ayrılmasıdır. Bu bakımdan kendine özgü yerle ve süreyle sınırlanmıştır. Oyun başlar ve belli bir noktada biter. Bir sonuca yöneliktir. Bir gelenek gibi süreklidir, tekrarlanır." (And, 2012, s. 28).

Oyunun sinırları vardır ve bu sinırlar zamansal ve mekânsal sinırlardır. Oyun, oyun alanında geçmektedir; aynı zamanda şu da ifade edilmelidir ki, oyuna konu olan mekân maddesel bir mekân olmak zorunda değildir. Hemen hemen tüm oyun argümanlarında, oyun söz konusu olduğunda mutlak surette oyun alanı/oyun sahası da devreye girmektedir. "Huizinga'ya göre, belli bir zaman ve mekân sınırı içinde gerçekleşen bütün oyunlar, ya maddi ya da maddi olmayan bir tarzda (ideally) ve de önceden kasti ya da olağan bir biçimde işaretlenmiş bir oyun alanının (play-ground) içinde kendi varlık[lar]ını sürdürürler." (Dursun, 2014, s. 152). And'ın da ele aldığı gibi, Huizinga'da oyunun başlıca özelliklerinden birisi gündelik yaşama ara vermek özelliğidir. Gündelik yaşama ara verildiğinde öznenin kendi varoluşunu sürdürdüğü kurallara sahip ve kendine özgü sınırları içinde eylenebilen alan, oyunun alanları olarak karşımıza çıkmaktadır. "Huizinga bu özerk oyun alanlarına, 'bildik dünyanın ortasında, belirli bir eylemin gerçekleştirilmesi amacıyla tasarlanmış geçici dünyalar' olarak bakar. Gene de oyun sahalarında göze çarpan en önemli şey, oyunun kendine özgü düzenidir. Oyun hem bir düzen yaratır, hem de kendisi bir düzendir. (Dursun, 2014, s. 153). Bu sayede, oyun oynayan insan, yani homo ludens, artık aklını kullanan insan ve üreten insan tanımlarından -yani homo sapiens ve homo faberden farklılaşmış bir insan tanımını getirmektedir. Burada oyun ve oyun sahası kadar oyuncular da bir farkındalığın konusu olarak kendi varoluşlarını gündelikten ayırmayı haiz olurlar. "Oyuncular giyimini kuşamını değiştirerek, maske takarak kendisinden başkası olmaktadır. Nitekim dramatik sanatın en önemli niteliği olan, bu kendisinden başkası olmak.” (And, 2012, s. 29). Demek ki homo Lludens olarak oyuncular -yani oyun oynayan canlilarvaroluşlarının hakikat iddiasından vazgeçmekte ve başka bir dünyanın fark’lı (différance akla gelmeli) sinırlarında var olmaktadır.

Oyunun Huizinga'da karşımıza çıkan en belirgin özelliği, kendine has kurallarıyla özerk alanlar açıyor olmasıdır. "Huizinga' ya göre oyun, belli bir zaman içerisinde başlar ve biter. Sonrasında, 'asıl' dünya hüküm sürer.” (Dursun, 2014, s. 154). Tam da bu noktada Huizinga'nın hakikât, asıl dünya, gerçek-anlatı karşıtllğı noktasında konumlanmaya çalıştığ 1 tavrın bir eleştirisi de söz konusu olmaktadır. Bu çalışmada sahiplenilen ve delilik meselesiyle birlikte alınan oyun kavrayışına göre; oyunlar bitmez, oyunlar her zaman birbirine bağlanır, başlar biter ve bu şekilde yaşamın gündelikliğinin içinde sürekli görünüp kaybolan unsurlar olarak var olmaya devam eder. Yani, Huizinga'nın söylediği gibi asıl dünyadan bağımsız olarak değerlendirilmemelidir. Oyun, her zaman asıl dünyanın içinde, kişinin sürekli devam eden kimliklenme halinde oluşunun bir tür yansıması ya da kavramsallaştırılmasıdır

Fink’e göre, “oyun, yaşamımızın sürekliliğini ve amaçsal yapısını kesintiye uğratır ve varoluşumuzun genel kipinden bir mesafeyle ayrılır." (Dursun, 2014, s. 156). Bu bakımdan Fink'in oyun kavrayışının da Huizinga'nınkine benzer olduğu söylenebilir. Ancak, Fink'in oyun kavrayışı, tam da yaşamın her bölümünde -ya da her tanımlanabilir farklı aşamasında- var olan bir tür yaşama potansiyellerinin sembolize edilmesi olarak karşımıza çıkmaktadır. "Bizler ciddiyeti oynuyoruz; sahiciliği oynuyoruz; gerçekliği oynuyoruz; iş ve mücadeleyi oynuyoruz; sevgi ve ölümü oynuyoruz. Üstüne üstlük, bir de oyun oynuyoruz.” (Fink, 2015, s. 18). Ona göre her türden fenomen, her şeyin bir anlamda sembolik bir temsilin unsuru olabildiği oyun dünyasında oynanmaktadır. Varoluşsal bağlamda düşünecek olursak, özetle şunu 
söyleyebiliriz: oyun yaşamın bizatihi kendisidir ve oyuncula da yaşam içinde doğaçlama oyunlar içinde var olur. Önemli olan ise bunun farkında olup olmamaktır. ${ }^{8}$

Oğuz Atay’ın “Günlük”ünde yazdığı üzere, “Tehlikeli Oyunlar” ismi, Eric Berne'ün "Hayat Denen Oyun"9 ("Games People Play") kitabında geçen kötü oyunlar (bad games) kavramından esinlenerek oluşturulmuştur. (Atay, 2016, s. 32). Özetle, insanların sürekli oyunlar oynadığı ve tutunamayan insanların tehlikeli oyunlar içerisinde varoluş problemini sürdürdüğü düşüncesine dayanmaktadır. Bu bağlamda değerlendirildiğinde, Oğuz Atay'ın oyuna yaklaşımı da bir tür postmodern yaklaşımın ifadesi olarak okunabilir. Çünkü; Moran'ın da belirttiği gibi; “Postmodern romanın bir özelliği de sanatı bir tür oyun olarak görmesidir. Sanat ile oyun arasındaki benzerliklere daha önce de işaret edilmiş ve Freud da, sanatın, çocukluktaki oyunun yerini tuttuğunu söylemişti. Ama postmodern romanda, oyun oynama bilinçli bir şekil alır ve yazar, kurgulama eylemini, okura, bir oyun gibi seyrettirir.” (Moran, 2001, s. 265). Bu noktada oyunun hakikate tekabül edip etmemesi tartışmasına da bir açıklık getirilmiş olmaktadır. Postmodern argümanlara paralellik arz edecek biçimde, bu çalışmanın göstermeye çalıştığ 1 temel hususlardan biri, bir anlatı olduğu açıkça dile getirilen romanın ve roman karakterlerinin aynı zamanda gerçek yaşama dair birer potansiyeli göstermeleridir. Şöyle söylüyor Oğuz Atay: "Çok büyük ve sonsuz bir oyunun bölümleri gibi bu oyunlar. Yüzyıllarca önce başlamış ve bir türlü bitmek bilmeyen entrikalar, heyecanlar, 1stıraplar, kıskanmalar, yükseliş ve düşüşler. Hayal gücü bir yerde beylikleşiyor. Gerçek hayattaki insanların çoğu da öyle. Verilen rolü oynayıp duruyorlar.” (Atay, 2016, s. 36). Demek ki, Atay’ın görüşünde yalnızca bir roman oyunundan, sıradan yaşamdan ayrılarak gündeliğin dışına çıkan kurgusal oyunlardan bahsetmiyoruz; askine, gerçek yaşamın ve gündelik olanın her anında türlü oyunlar içerisinde var olmaktan başka bir çaremiz yoktur denilebilir. Bu noktada yapılması gereken şey, oyun oynadığımızı fark ederek, oyunları daha çok kendimiz kurgulamak şartıyla onları özgürce yönlendirebileceğimiz delilik oyunlarına dönüştürebilmektir.

Oğuz Atay, "Tehlikeli Oyunlar"ın sonunu da oyun ve gerçek hayat arasındaki silikleşmiş irtibatla düşünmektedir. "Hikmet'in ölümü bu gecekondu semtinde, çok gürültülü ve trajik bir sahne sonunda olacak. Ölüm, bir piyesle karışık ve oyun ile gerçeğin karıştığı bir atmosferde verilecek. Gerçek yaşantı bitecek oyun devam edecek." (Atay, 2016, s. 46). Hakikât ve anlatı arasındaki bu silikleşen irtibat göz önüne alındığında Oğuz Atay’ı ve başta "Tehlikeli Oyunlar" olmak üzere romanlarını ve öykülerini bu tarzda yorumlamak daha anlaşı1ır hâle gelmektedir.

\section{Delilik Oyunu ve Hikmet Benol Karakteri}

Son olarak, delilik ve oyun meselelerini bir araya getirmek suretiyle -yani delilik oyunu şekline büründürdükten sonra- tutunamayanların en tutunamayan karakteri olarak Hikmet Benol'un bu bağlamda nasıl değerlendirilebileceğini göstermek gereklidir. Özet bir ifadeyle söylemek gerekirse, bu çalışmada delilik kavramı, logosla -yani akılla ve düzenle- karşıt olarak konumlandırılması nedeniyle kullanılmıştır. Foucault'nun da söylediği gibi, delilik -bazen olumlu bazen olumsuz şekilde- tarih boyunca her dönemde anormalin temsili olmuş, normal olana aykırılığ 1 temsil etmiştir. Bahsettiğimiz oyun mefhumunun, yani yaşam içinde sürekli oynadığımız çeşitli oyunların belli bir düzende değil de rastgele/rastlantısal bir biçime bürünmesini sağlayan şey, tam da hayat denen oyuna dokunan delilik tılsımı olarak görülmelidir.

Hikmet Benol, oyunlarla yaşayabilen, ancak oyun bittiğinde (logos başladığında) ortadan kalkan bir karakterdir. Gündelik yaşam Oğuz Atay için bir oyun sahnesidir. Ancak "Roman kişisi Hikmet bu oyuna katılmak istememektedir, 'oyuna gelmemek' için gecekonduya taşındığını söyler.” (Ecevit, 2014, s. 346). Hikmet Benol, yaşamın oyuna en müsait alanını mekân olarak seçmiştir. Esasında söylediğinin arkasında yatan şey, oynanan logos oyunlarına katılmamak, kendi oyunlarını yazabilmektir. Yani, oyunlar oynayan bir insan olarak, geçmişin logosta kendini var eden rasyonel kısmından kurtulmak ve bir anlamda irrasyonel

\footnotetext{
${ }^{8}$ Bu noktada bir tavsiye olarak Derrida'nın différance argümanı, Deleuze'ün rhizome kavramı gibi kökenden ziyade köksüzlüğe ve farkın kuruculuğuna vurgu yapan postmodern denilebilecek yaşam anlamlandırması örneklerine bakarak konu genişletilebilir.

${ }^{9}$ Bkz. Berne, 1976.
} 
olanın, delice olanın tarafinda kendi oyunlarını inşa edebilmektir. Bu bağlamda gecekondu imgesinin de oldukça önemli olduğunu belirtmek gerekmektedir.

“Tehlikeli Oyunlar"ın Hikmet Benol karakteri için oyunun ontolojik bir karakteri vardır. "Bir gün sonraya çıkabilmek için ve güneşin bir gün daha doğmak üzere olduğunu görebilmek için”" (Atay, 2015, s. 317) yeni oyunlar icat etmek, yani yazmak zorundadır “Tehlikeli Oyunlar"ın Hikmet'i. "Oğuz Atay'ın 'düşünen insan'1, böylece 'oynayan insan'a (homo ludens'e) dönüşmüştür. (Çapan, 1984, s. 7). Tehlikeli oyunlar oynayan homo ludens olarak Hikmet Benol, varoluşun karmaşıklığı karşısında bu şekilde ayakta durmaktadır.

Oğuz Atay'ın genel kavramsallaştırmayla tutunamayan karakterlerinin çerçevesi Don Kişot'la, Dostoyevski'nin yabancılaşmış karakterleriyle, Kafka'da ve Camus'de karşımıza çıkan yaşamla sorunu olan ve onu bir biçimde kabullenemeyen karakterlerle bir akrabalığa sahiptir. "Oğuz Atay'ın 'tutunamamak' olarak nitelediği, bugün neredeyse bir kavram olarak kullandığımız durum, her kanunun dışında olma hali, hiçbir kanunun içine girememe, kanun tarafından korunmama, ya da kanunun sahibi-temeli olmama, dolayısıyla iktidarsız olma hali.” (Ertuğrul, 2012, s. 81). Oğuz Atay da, özellikle Dostoyevski, Kafka, Musil gibi isimlerle bu tarzda düşünsel bir akrabalığı taşımaktadır. Eserlerinden, -özellikle de "Tehlikeli Oyunlar"dan- çıkan isimler, bir yandan deli/mecnun/serseri/picoro tarzı toplum dişı kahramanlarken, diğer yandan Atay'ın bizatihi kendi yaşamının karakterleridir.

Hikmet Benol'un varoluş sorunsalı, modernitenin ve Kartezyen akılcıllğın karşısında yer bulmaya çalışan bireyin problemini temel almaktadır. Romanın en önemli bölümlerinden birisi olarak karşımıza çıkan Büyük Oyun başlıklı bölümde bir tür devrimden bahseder Hikmet; devrim sonucunda insanın kendisini yalansız yaşaması gerçekleşecek, herkes özbenine kavuşacaktır. Bunun yolu da soyut düzlemde bir tür sınıf çatışmasından geçmektedir: "Dünya ikiye ayrılmalı. Yeter derecede bir arada yaşandı. Descartes'ın kurallarına göre yaşamak isteyenler ayıklanmalı artık." (Atay, 2015, s. 350) demektedir. Dolayısıyla, varoluşunu aklın karşısına, logosun zıttına, deliliğin tarafına koymaktadır.

Hikmet Benol'da karşılaştığımız eleştiri, tam da Derrida'nın bahsettiği gibi ironiyle var olan bir tür eleştiridir. Logos düzenine dahil olmaktan sıyrılmanın en mümkün özelliği olan ironi, Oğuz Atay'ın kaleminde alay (mocking) olarak karşımıza çıkmaktadır. "Atay, hicivci değildi; çünkü okuruyla paylaştığı bir zemin, bir hakikat yoktu. Oysa hicivde hep bir doğru vardır, hicivci karşısındakiyle alay ederek, onu gülünçleştirerek bu doğrunun görünmesini sağlar. Alay ettiği şeyle kendisi arasındaysa mutlak, aşılmaz bir duvar vardır. ... Şöyle der hicivci: 'Sen kendini akıllı zannediyorsun, ama aslında budalanın tekisin.' " (Gürbilek, 1990, s. 7-8). O halde, Atay'ın ironisini bir tür dekonstürksiyon örneği olarak düşünmek mümkündür. Zira, dekonstrüksiyonda olduğu gibi, mevcudiyete, şimdide var olan her tür sabitliğe karş1 çıkışı ifade eder. Aklın karşısına -ya da dışına- dokunan, Kartezyen düşüncenin dekonstrüksiyonuna yönelen Hikmet Benol'un durumu, "Tehlikeli Oyunlar"1n En Büyük Hazinemiz Aklımızdır başlıklı on beşinci bölümünde net olarak karşımıza çıkmaktadır. " 'En büyük hazinemiz aklımızdır' diyerek, aklı herkesten önce kendisi gülünç kılarak, aklın soytarısı olmayı kendisi üstlenerek, başkalarının onu 'gayri ciddiye' almasını engeller.” (Gürbilek, 1990, s. 18). Bu yöntemle, yani çifte ironi/ çifte alay diyebileceğimiz yöntemiyle, kendini ve ironiye konu ettiği nesneyi korumaya alabilmektedir. Tam da metnin başında belirtildiği gibi, mesele kelimelerdir ve Atay kelimelerle istediği gibi oynamaktadır.

Oyun ve anlatılar arası aporetik durum (uzlaşmaz/çözümlenemez içsel çatışma durumu) söz konusu olduğunda, geleneksel anlatılarda karışımıza çıkan Newton fiziğinin yasalarına uygun zaman ve mekân kategorileri de devre dışı kalmakta, aporiaya ayak uydurmaktadır. İlerleyen düz bir zaman ve belirlenebilir mekânlar söz konusu değildir. "Romanda metin içi öyküler (2. düzlem) ve anılarla (3. düzlem) belirsizleşen zaman-mekân sınırları, somut yaşam düzleminde (1. düzlem) ise neden-sonuç ilişkisi mantığının dışına itilir.” (Ecevit, 2014, s. 358). Artık gerçekliği aramak, geleneksel modern anlatılardaki kurguları izlemek ve ayrıştırmak oldukça zorlaşmıştır. 
Atay'ın eserlerinin birçok anlamda otobiyografik özellikler taşıdığı daha evvel de belirtilmişti. Bu önemli özellik, onun eserlerini ontolojik bir boyuta taşımakla birlikte, yarattığı karakterlere dair niteliklerin biçimlenmesinde de önem arz etmektedir. Tümü birer yorum olmakla birlikte Tehlikeli Oyunlar'ın üç önemli karakterinin, yani Albay'ın, Sevgi'nin ve Bilge'nin, Hikmet'in hayatında olduğu kadar Atay'ın hayatında da karşılıkları mevcuttur. Örneğin, hayatında en değer verdiği dostlarından biri olarak ifade edilebilecek kişi, "Oğuz’un ömrünün sonuna değin arasının hiç açılmayacağı, onu farklı bir şekilde anlayan, kendisinden on iki yaş büyük olan ve çoğu zaman da ona babalık yapan öykü yazarı Vüs'at Bener ... 'Ne karanlık ruhun var yahu Hikmet! Biraz pencereni aç da içeri temiz hava girsin' diyen Emekli Albay Hüsamettin Tambay'd1." (Güneş, 2015, s. 5). Hikmet Benol, tüm kurgusunun en üst katmanında Hüsamettin Albayım'la sohbet etmekte, diğer katmanları onunla birlikte kurmaktadır. Ancak Albayım, Hikmet'in oyunlarında baş karakterlerden biri olmasına rağmen, Hikmet'in deliliğine karşı akılcılığ anlatının özelliklerini savunan bir karakter olarak karşımıza çıkmaktadır.

Albay karakteri Hikmet'in varlığı için kuşkusuzdur; ancak okuyucular için kuşkulu bir kurguda var olur. "Hikmet kendi yarattığı oyunlarla delirecek duruma gelmiştir. ... Hikmet hepsini kovar ve bütün olayları düzelten oyunlar oynar kafasında. ... Balkona hava almaya çıkar ve balkondan düşer, ya da atlar. Bu da belli olmaz. Hüsamettin Bey de bu olaya bir 'oyun' yazar. O da yarı delidir." (Atay, 2016, s. 66). Hüsamettin Bey, nam-1 diğer Albayım, gerçekliği şüpheli olan, asıl işlevi Hikmet'in delice tavırlarına karş1 dengeleyici bir unsur olarak onu akla davet eden karakterdir. Ancak, kendisi de bir miktar deliliğin içindedir; belki de Hikmet'ten farklı bir karakter olmadığı için.

"Tehlikeli Oyunlar"ın sonu, bir intihar olarak karşımıza çıkar. Kitabın on yedinci bölümünün adı Düşüş’tür (Atay, 2015, s. 447-462) ve bu bölüm Son Yemek (Atay, 2015, s. 424-446) isimli bölümün ardından gelmektedir. Son Yemek bölümü, büyük bir şölenin, herkesin yer aldığı bir ziyafetin anlatıldığı, $\dot{I}_{s} a$ 'nın son yemeğine benzer bir sahnenin canlandırıldığ bölümdür. Bu bölümde deliliğin şöleni diyebileceğimiz bir anlatım vardır. "Son Yemek' bölümü, klasik anlamda ele alındığında kurgusal bir doruktur, bir klimakstır.” (Ecevit, 2014, s. 349). Tüm tutunamayanlar burada şölenin bir parçası olurlar. Buradaki en fazla önem arz eden ayrıntılardan birisi, yemeğe Bilge'nin çağrılmamış olmasıdır. Çünkü Bilge, bilgedir, akıldır. Deliliğin şöleninde yeri olmamalıdır. Bunun ardından gelen düşüş ise, tam anlamıyla bir düşüştür. Şölenin ardından gelen yok olma ile Hikmet gerçek anlamda çakılmıştır. Kendisiyle hesaplaşıp, en derin hesaplaşmasını gerçekleştirip pencerede aşağı atlar.

Hikmet'in intiharı da kesin olmayan bir ölümü, öl-müş gibi yapmayı ifade etmektedir. Hikmet'in “Tehlikeli Oyunlar”daki son sözü, düşünüyorum olmuştur. (Atay, 2015, s. 462). Düşünmek ve düşmek arasındaki kelime oyunu oldukça önemlidir. Özetle ifade edilecek olursa Hikmet'in düşünmesi onun ölümü olmaktadır. Bu noktada son olarak, ilk kısımda ele alınan logos-delilik karşıtlığına dair anlatılara dikkat çekmek gereklidir. Hikmet, logos düzenine düşmüş, deliliğin düşünden uyanmış ve tehlikeli oyunlarının sonuna gelmiştir. Bu nedenle, gerçek bir intihar olarak pencereden dü̈smek ile sembolik bir intihar olarak düşünmek arasındaki dil oyunu, Hikmet’in son oyunu olarak ifade edilebilir.

Son olarak, şunu söylemek mümkündür: Oğuz Atay’ın başyapıtı olarak ifade edilebilecek “Tehlikeli Oyunlar” metnini (“Tutunamayanlar”la birlikte) oyun ve delilik kavramlarının düzenle, akılla, logosla olan karşıtlığı sayesinde, varoluşun bir tür delilik oyunu olarak kavranması biçiminde okumak mümkündür. Bu okuma, bize gündelik yaşamlarımızda oynadığımız oyunların belki biraz daha delice olması gerektiğini, logos düzeninin monoton ve tekdüze yapısını, tektipleştirici modern aklın eleştirisinin gerekliliğini gösterecektir diyebiliriz. Bunun ötesinde metin sadece kısa bir olayı ifade etmektedir. Sözü Atay'a birakacak olursak;

Hava kararıyordu. Köşeden bir genç kızla bir genç adam göründü kol kola. Delikanlı bir şeyler anlatıyordu, genç kız da başını sallıyordu. 'Bana kalırsa film biraz karışıktı,' dedi genç adam. 'Bazı yerlerini anlamadım.' 'Canım,' dedi kız, 'Sonunda çocuk ölüyor işte.' 'Aptal,' dedi delikanlı, 'O kadarını biz de anladık'. (Atay, 2015, s. 474). 
Aslında bütün hikâye budur...

\section{Sonuç}

Bu çalışmada, Oğuz Atay'ın eseri olan “Tehlikeli Oyunlar” ve bu eserin baş karakteri olan -aynı zamanda Atay'ın eserlerinin tamamı göz önüne alındığında en önemli karakterlerinden birisi olarak tarif edilebilecek- Hikmet Benol karakterini belli bir bağlam içerisine oturtarak yorumlama denemesi yapılmaya çalışı1mıştır. Çalışmanın odağı "Tehlikeli Oyunlar” metni ve Hikmet Benol karakteri olmakla birlikte, bahsi geçen belirli bağlamın inşa edilmesi adına delilik ve oyun kavramlarına başvurulmuştur. Böylece, bir homo ludens olarak tanımlanan Hikmet Benol'un delilik ve oyun ile örülen bağlama yerleştirilmesi amaçlanmıştır.

$\mathrm{Bu}$ amaca uygun olarak Oğuz Atay’ın edebiyat dünyasında nerede durduğu kısaca açıklanmaya gayret edilmiştir. Görüldüğü üzere, Oğuz Atay’ın hemen her eseri -ve tabi ki “Tehlikeli Oyunlar” adlı eserimodern roman anlayışının klasik ve toplumcu bakış açılarından sıyrılan, farklı tarzda bir eleştirelliği ironi ve alay unsurlarıyla kurabilen, aynı zamanda farklı edebî türlerin bir arada kullanımı, üstkurmaca -anlatı içinde anlat1- ve metinlerarasılık gibi özellikleriyle birlikte değerlendirildiğinde postmodern roman anlayışının Türkiye' deki en önemli -ilk örneklerinden- temsilcisi şeklinde tanımlanabilecek bir yazar olarak karşımıza çıkmaktadır.

Atay'1 ve bu çalışmada ayrıca üstünde durulan Hikmet Benol karakterini yorumlama çabası, bir yandan delilik mefhumunun dışlanma, başka yerden olma, normlara uymama, logos düzenine aykırılık teşkil etme gibi özellikleri ile bağdaştırılmış, diğer yandan oyun mefhumunun varoluşla ve gündelik yaşamla irtibatı minvalinde oyunla ilişkilendirilmiştir. Bu şekilde karşımıza çıkan delilik oyunu bağlamı, tam da "Tehlikeli Oyunlar"1 ve homo ludens olarak Hikmet Benol'u yorumlamanın yeni ve farklı bir biçimi olarak değerlendirilebilir. Son bölümde de görüldüğü gibi, Oğuz Atay’ın en tutunamayan karakterlerinden birisi olan Hikmet Benol'un yaşamı, tam da kurulmaya çalışılan delilik oyunu bağlamına uygun, varoluş problemini hayatının en derinlerinde hisseden, sonuçta ise delilikten uyanarak düş(ün)en bir intihara konu olmuş, tanımlanması ve tarif edilmesi zor bir yaşamın ontolojik sancıları olarak değerlendirilebilir.

Elbette delilik ve oyun mefhumları, yalnızca postmodern bir bağlamın konusu değildir. Foucault'da gördügümüz gibi, meselenin oldukça somut, köşeli sınırlarla ayrılan modern minvalde bir politik/pratik yanı da mevcuttur. Çalışmada öne çıkarılan nokta ise, temelde hakikâtin ve kurgunun gündelik yaşamlarımızdaki müphemliğidir. Meseleyi postmodern bir çizgiye çeken bu nokta, müphemliğin günümüz dünyasının kaçınılmaz çerçevesi olmasından ileri gelmektedir. Aynı zamanda, bahsi geçen politik/pratik bağlam, görüldüğü gibi kurgunun gerçekle iç içe geçtiği gündelik yaşamlarımızın bir yorumu hâlini almaktadır. Günümüz dünyasını anlamlandırmak ve/veya yönetmek/yönlendirmek için harcadığımız şahsî ya da politik çabalar, yalnızca bireysel düzlemde değil, toplumsal ve hatta küresel düzlemde de hakikât/kurgu belirsizliğini göz önünde bulundurmak zorundadır. Bu bağlamda, varoluşsal çıkışsızlığın üstesinden gelmenin bir yolu, delilik mefhumundan beslenen bir homo ludens olarak yaşamak olabilir. Bunun en basit ifadesi, kişinin delilik oyunları oynayan bir homo ludens olması, böylece kendi -gerçek/kurgu belirsizliğinde var olan- yaşamını bizatihi kendisinin üretebilmesidir. Sonuçta, Hikmet Benol karakteri de bu yoruma uygun olarak değerlendirilebilecek bir potansiyel yaşam imkânı biçiminde görülebilir ve bu sayede oldukça güçlü ve çarpıcı bir figür olarak gerçek yaşamlarımızın içinde yer alabilir.

\section{Kaynakça}

Akatlı, F. (2012). Öykücü Oğuz Atay. H. İnci ve E. Türker (Haz.), Oğuz Atay Iç̧in Bir Sempozyum içinde (ss. 43-49). İstanbul: İletişim Yayınları.

And, M. (2012). Oyun ve bügü: Türk kültüründe oyun kavramı (3. bs.). İstanbul: Yapı Kredi Yayıları. 
Atay, O. (2008). Tutunamayanlar (42. bs.). İstanbul: İletişim Yayınları.

Atay, O. (2015). Tehlikeli Oyunlar (33. bs.). İstanbul: İletişim Yayınları.

Atay, O. (2016). Günlük (22. bs.). İstanbul: İletişim Yayınları.

Aygün, A. (2012). Oyunumuzdan bunalan Homo Ludens Disconnectus Erectus’u Kuramsal Oku-ma-ma Denemesi. H. İnci ve E. Türker (Haz.), Oğuz Atay Iç̧in Bir Sempozyum içinde (ss. 139-148). İstanbul: İletişim Yayınları.

Berne, E. (1976). Hayat denen oyun. S. Sargut (Çev.). İstanbul: Altın Kitaplar Yayınevi.

Çapan, C. (1984). Önsöz. Tehlikeli Oyunlar içinde (ss. 5-8). İstanbul: İletişim Yayınları.

Dede, K. (2016). A way of opposition: Turkish literature and instrumental madness. A. Klaumbauer (Ed.), Muses, Mystics, Madness: The Diagnosis and Celebration of Mental Ilness içinde (ss. 79-88). Oxford: Inter-Disciplinary Press.

Derrida, J. (1982). Margines of philosophy. Chicago: The Harvester Press.

Dursun, Y. (2014). Oyunun ontolojisi. Ankara: Doğu Batı Yayınları.

Ecevit, Y. (2014). “Ben buradayım... ”: Ŏguz Atay’ın biyografik ve kurmaca dünyası. (6. bs.). İstanbul: İletişim Yayınları.

Erasmus, D. (2008). Deliliğe övgü. H. İlhan (Çev.). Ankara: Alter Yayınları.

Ertuğrul, S. (2012). Kanundış1: Tutunamayanlar. H. İnci ve E. Türker (Haz.), Oğuz Atay İçin Bir Sempozyum içinde (ss. 79-88). İstanbul: İletişim Yayınları.

Felman, S. (1975). Madness and philosophy or literature’s reason. Graphesis: Perspectives in literature and philosophy. Yale French Studies, 52, 206-228.

Fink, E. (2015). Bir dünya sembolü olarak oyun. N. Aça (Çev.). Ankara: Dost Kitabevi Yayınları.

Foucault, M. (2015). Deliliğin tarihi (6. bs.). M. A. Kılıçbay (Çev.). Ankara: İmge Kitabevi.

Güneş, S. (2015). Kelimeleriyle ölümü ve sonsuzu kucaklayan yazar: Oğuz Atay. Kafkaokur, 7, 2-11.

Gürbilek, N. (1990). Kemalizmin delisi Oğuz Atay. Defter Dergisi, 14, 7-19.

Huizinga, J. (2015). Homo Ludens: Oyunun toplumsal işlevi üzerine bir deneme (5. bs.). M. A. Kıl1çbay (Çev.). İstanbul: Ayrıntı Yayınları.

Lucy, N. (2012). Yapısöküm. Derrida Sözlüğü içinde (ss. 208-210). Ankara: BilgeSu Yayıncılık.

Moran, B. (2001). Türk romanına eleştirel bir bakış 2: Sabahattin Ali'den Yusuf Atılgan'a. (7. bs.). İstanbul: İletişim Yayınları.

Ramond, C. (2011). Déconstruction (Yapıbozum/Yapısöküm). Derrida Sözlüğü içinde (ss. 58-63). İstanbul: Say Yayınları.

Scull, A. (2016). Uygarlık ve delilik. N. Elhüseyni (Çev.). İstanbul: Yapı Kredi Yayınları.

Vahaploğlu, Z. (2014). Foucault, Derrida ve Erasmus’ta delilik. (Yüksek lisans tezi). Gazi Üniversitesi, Sosyal Bilimler Enstitüsü Felsefe Anabilim Dalı. 